U.S. Department of Agriculture

Animal \& Plant Health Inspection Service

Wildifife Services

December 2016

Wildlife Damage Management

Technical Series

\title{
Hawks and Owls
}

Brian E. Washburn

Research Wildlife Biologist USDA-APHIS-Wildlife Services National Wildlife Research Center Sandusky, Ohio

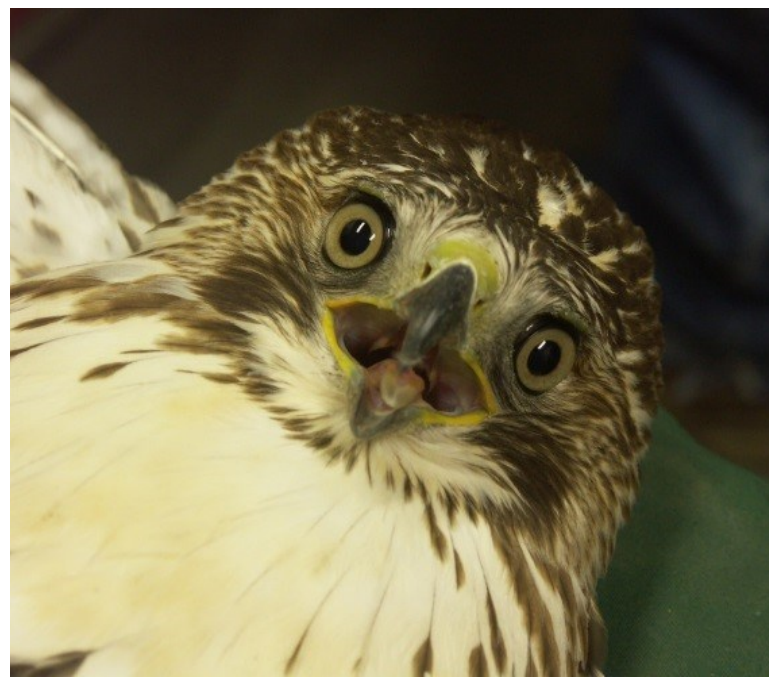

Figure 1. Red-tailed hawk (Buteo jamaicensis).

\section{Human-Wildlife Conflicts}

\section{Quick Links}

\begin{tabular}{|ll|}
\hline Human-Wildlife Conflicts & 1 \\
Damage Identification & 3 \\
Management Methods & 3 \\
Economics & 8 \\
Species Overview & 9 \\
Legal Status & 13 \\
Glossary \& Key Words & 14 \\
Resources & 15 \\
Appendices & 16 \\
\hline
\end{tabular}

Hawks and owls can negatively impact a variety of human interests, including important natural resources, livestock and game bird production, human health and safety, and companion animals. Conflicts between raptors and people generally are localized and often site-specific. However, the economic and social impacts to the individuals involved can be severe.

Despite the problems they may cause, hawks and owls provide important benefits and environmental services. Raptors are popular with birdwatchers and much of the general public. They also hunt and kill large numbers of rodents, reducing crop damage and other problems.

\section{Natural Resources}

Hawks and owls can negatively affect other species of wildlife by constant predation and additive mortality. Great horned owls (Bubo virginianus), and occasionally red-tailed hawks (Buteo jamaicensis), (Figure 1), can severely impact colonial waterbird and shorebird nesting colonies by concentrating their hunting efforts on specific colony sites and attacking both chicks and adults. This can 
be especially problematic if the nesting birds are rare or have threatened and endangered species status.

Great horned owls are formidable predators that kill and eat other raptors, such as peregrine falcons and young osprey. Such predation events can be costly to reintroduction programs with the goal of increasing raptor numbers in these areas.

In the western United States, populations of barred owls (Strix varia) currently are expanding into many new areas and aggressively displacing (meaning they physically attack and sometimes eat) spotted owls (S. occidentalis) in forest habitats. Spotted owls are a native owl of significant conservation concern.

\section{Livestock and Pets}

The majority of depredation problems involving livestock occur with free-ranging farmyard poultry and game farm fowl (Figure 2). In North America, hawks that are perceived as predators on domestic fowl are called "chicken hawks." Chickens, turkeys, ducks, geese, and pigeons are vulnerable because they are conspicuous, unwary, and usually concentrated in areas that lack escape cover. Confined fowl that are chased by hawks and owls often pile up in a corner, resulting in the suffocation of some birds. Reproduction also may be impaired in some fowl if harassment persists.

Game farms and operations that rear game birds have dealt with raptor depredation problems for many years. Large concentrations of game farm animals, especially birds such as pheasants and quails, are attractive to hawks, owls, and predatory mammals, such as coyotes, raccoons, and weasels. Operators should consider the prevention of predation as part of their cost of operation. Accipiters and falcons commonly chase and upset penned game birds until they flush and stick their heads through the netting of the pen, giving the raptor a chance to attack. Hawks and owls also kill rabbits at hunting clubs where dogs are trained and homing and racing pigeons.

Hawks and owls are highly opportunistic predators. Small dogs, cats, kittens, and caged pet birds left outside and

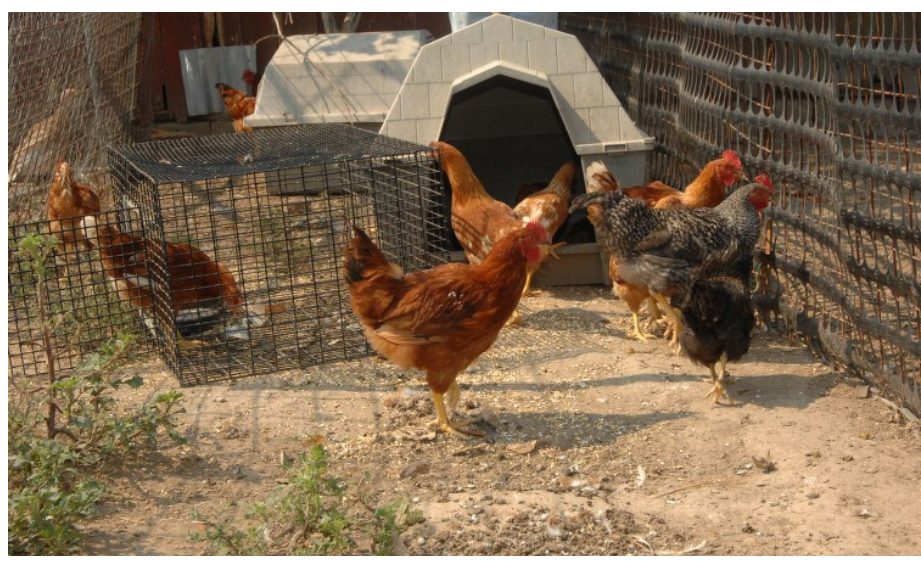

Figure 2. Backyard chickens (above), turkeys, and ducks are vulnerable to predation by raptors.

unattended occasionally are at risk of attack and predation. The frequency and severity of such incidents may increase during winter when food is scare or during early summer when newly fledged young are developing their hunting skills.

\section{Structures}

Hawks and owls commonly are electrocuted when perching on high-energy electric transmission poles. Hawks nesting on electric transmission towers and poles, cellular towers, and other utility structures can cause fires, interrupt service, and interfere with maintenance activities.

\section{Human Health and Safety}

Hawks and owls pose a risk to safe aircraft operations due to bird-aircraft collisions (also known as bird strikes). Hawks and owls commonly use the large, open grasslandlike habitats of airports and military airbases for feeding (Figure 3). The relatively large size of hawks and owls increases the risk of damage to aircraft. Bird strikes can result in significant and costly damage to aircraft, as well as human injuries and fatalities.

Hawks and owls can be aggressive toward humans and inflict serious cuts and lacerations with their talons. In 
particular, during the nesting season hawks and owls defend their nests and young with great ferocity. These negative interactions occur most frequently when hawks and owls are nesting in urban and suburban areas.

\section{Nuisance Problems}

Generally, nuisance problems with hawks and owls relate to the perceived risk to people and animals posed by these birds in urban and suburban areas.

\section{Damage Identification}

Poultry and other livestock are vulnerable to a wide range of predators. Frequent sightings of hawks and owls near the depredation site may be a clue to the predator involved, but these sightings could be misleading. The cause of death for a partially eaten carcass often is difficult to determine. In all cases, the remains must be carefully examined. Raptors usually kill only 1 bird per day. Raptor kills usually have bloody puncture wounds in the back and breast from the bird's talons. Owls often remove and eat the head and sometimes the neck of their prey.

Hawks pluck birds and leave piles of feathers on the ground, often in a circular pattern called a fairy ring. Beak

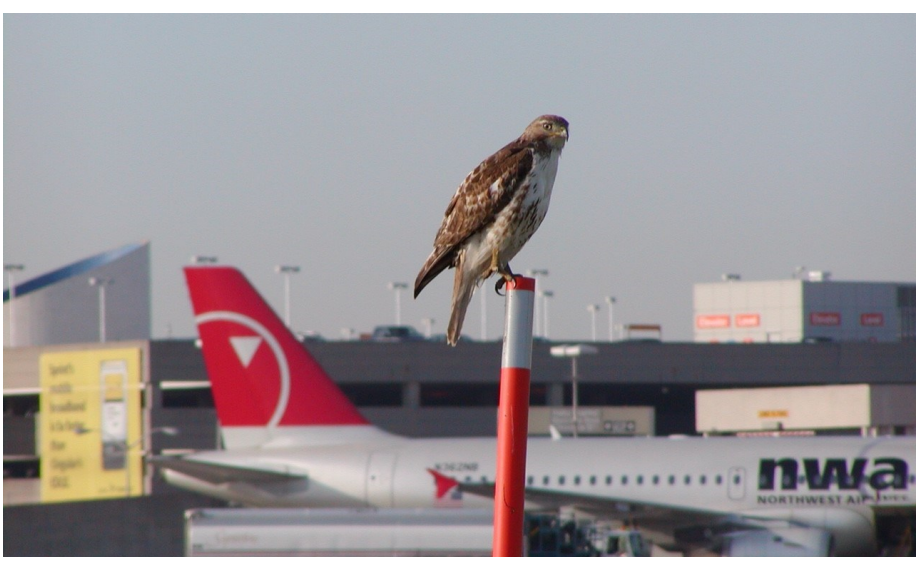

Figure 3. Raptors use airport grasslands and weedy areas to hunt for small rodents and other mammals. marks and damage, often in a V shape, can be seen on the shafts of these plucked feathers. Owls also pluck their prey, but at times, they swallow small animals whole.

In contrast, mammalian predators such as skunks or raccoons often kill several animals during a night. Weasels are known to go on "killing frenzies" and kill many more animals than they actually consume. Mammals usually tear skin and muscle tissue from the carcass and cut through the feathers of birds close to the body with their sharp teeth. Feathers often are strewn about randomly at kill sites involving mammals.

All raptors, but especially red-tailed hawks and other buteos, feed on carrion. The plucked feathers can often indicate whether a raptor actually killed an animal or was simply "caught in the act" of feeding on a bird that died from other causes. Feathers that have small amounts of tissue clinging to their bases were plucked from a cold bird that died from another cause. If the base of a feather is smooth and clean, the bird was plucked shortly after it was killed.

Raptors often defecate at a kill site. Accipiters such as the goshawk leave a splash or streak of whitewash that radiates out from the feather pile, whereas owls leave small heaps of chalky whitewash on the ground.

\section{Management Methods}

As with all wildlife damage management issues, an integrated program that uses several tools and techniques for reducing the severity, impact, and financial losses of hawk- or owl-related conflicts with humans is best. Information on the biology of the species involved is essential to the success of management efforts.

When considering which method(s) to use, one should consider the timing of such events, how cost-effective potential actions might be, whether the issue can be tolerated, and how the success of action(s) taken will be evaluated/monitored. Some methods will be too costly or impractical to implement, whereas other techniques might be fairly easy to use and achieve the desired outcome. 


\section{Habitat Modification}

Habitats can be modified to make an area less attractive to hawks and owls looking for an easy meal. Hawks and owls often use a hunting perch to survey an area before making an attack. Removal of hunting perches can be accomplished by cutting down snags and trees on which hawks and owls are commonly observed. Poles and other man-made perch sites should be modified with antiperching devices, such as sheet metal cones and electric shock strips and devices, to deter hawks and owls from using them.

Several anti-perching devices are commercially available, including Nixalite $\AA$, Cat Claws $\AA$, and inverted spikes, that help deter hawks and owls from using buildings, roofs, and other structures as perching and hunting sites.

Overhead wires made of nylon cord or heavy monofilament fishing line suspended in parallel over game bird pens, pet runs, and other areas where animals might fall prey are effective in deterring hawks and owls from swooping down and startling their intended prey.

\section{Exclusion}

The best solution to raptor depredation is prevention. Freeroaming farmyard chickens, ducks, and pigeons can be conditioned to move into coops or houses at night by feeding or watering them indoors at dusk.

Durable fenced enclosures can be constructed by securing poultry wire to a wooden framework and covering this enclosure with a second layer of poultry wire, nylon netting, or overhead wires. A double layer of overhead netting separated by a 5- to 6-inch space may be necessary to keep hawks and owls away from penned birds.

Companion animals (such as small dogs and cats) should be kept inside a fully enclosed pen or run while they are left unattended outdoors. Pet birds should be kept in a roomy cage, wire enclosure, outdoor aviary (can be made from hardware cloth), or screened room with locked doors. This is especially important at night to keep them protected from owls.

\section{Frightening Devices}

There are many techniques that can be used to disperse hawks and owls from an area where they are causing damage. Some are inexpensive and easy to use, whereas others are more complicated and costly. The effectiveness of frightening devices depends greatly on the bird, area, season, and method of application. Generally, hungry birds quickly habituate to and ignore frightening devices. Frightening devices usually reduce rather than totally eliminate losses. Landowners who use them must be willing to tolerate occasional losses.

Increasing human activity in the threatened area will keep most raptors at a distance. Air horns, banging pots and pans, and other methods of making loud noises at the offending bird can be effective, especially in suburban and urban areas where deployment of pyrotechnics and firearms is not advisable or allowed.

The most common and easily implemented frightening device is a shotgun fired into the air in the direction of (not at) the raptor. Firearm safety is of the utmost concern. Scarecrows can be effective at repelling raptors when they are moved regularly and used in conjunction with other bird dispersal methods.

Pyrotechnics include a variety of exploding or noise-making devices. Shell crackers, which are 12-gauge shotgun shells containing a firecracker that is projected 50 to 100 yards before it explodes, are commonly used. An inexpensive open-choke, single-shot shotgun is recommended. Check the gun barrel after each shot and remove any wadding or debris that may be lodged in the barrel. Screamers, bird bangers, and bird bombs are commercially available pyrotechnics that are fired from special pyrotechnicspecific pistols; their range is limited to 25 to 75 yards.

Fire pyrotechnics in the direction of hawks or owls (never directly at them) that are found within the area of concern. Local and national restrictions on the purchase, storage, and transportation of pyrotechnics may preclude use by some people. Your local fire warden can provide information on local or state permits that are required to possess and use pyrotechnics. 


\section{Repellents}

None are registered.

\section{Fertility Control}

Fertility or reproductive control typically is not used to manage wildlife damage associated with hawks and owls. Removal of nests, however, can alleviate problems related to aggressive individual birds or nesting pairs, but not when eggs or chicks are present. Nest management (e.g., oiling or addling eggs, replacing hawk eggs in active nests with domestic chicken eggs) can be used to reduce the number of hawks and owls within airport environments or other sensitive environments to increase human health and safety. State and federal permits are required.

\section{Toxicants}

None are registered. Historically, raptors were killed by putting out carcasses laced with poison. Indiscriminate killing of many nontarget animals and concerns for human safety prompted the banning of toxicants for raptor control.

\section{Shooting}

Federal and state laws protect all hawks and owls. Shooting can be authorized under depredation permits in specific situations involving public health and safety

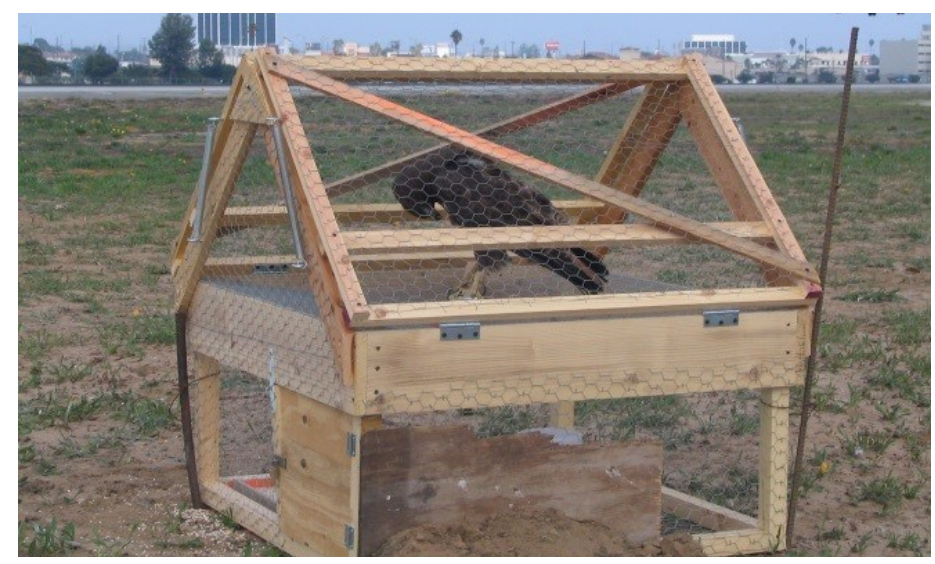

Figure 4. A Swedish goshawk trap. The trap is closed and a hawk is safely trapped inside the upper compartment. hazards or seriously affecting a person's livelihood. For example, authorized individuals may shoot a hawk posing a consistent, immediate, and imminent danger to aircraft at an airport. To obtain a federal depredation permit, first contact your local USDA-APHIS Wildlife Services (WS) office. The U.S. Fish and Wildlife Service (USFWS) and state wildlife agencies may issue depredation permits allowing for lethal control of problem hawks and owls, but will do so only if nonlethal methods of controlling damage have failed or are impractical and if it is determined that killing the offending birds will alleviate the problem.

Permittees may kill hawks or owls listed on the permit using a shotgun not larger than 10-gauge, fired from the shoulder and only within the area described by the permit. Proper firearm safety is of the utmost importance, especially in confined areas or extra-sensitive situations, such as active airfields or in populated areas. Permittees may not use blinds or other means of concealment, or decoys or calls to lure birds within gun range.

\section{Trapping and Translocation}

Live-trapping and translocating problem hawks and owls is a commonly used non-lethal method of resolving conflict situations with humans and raptors. State and federal permits are required. If possible, experienced bird banders or wildlife professionals with proper training should manage trapping efforts. Landowners and private citizens can safely live-trap hawks and owls if they obtain some instruction and carefully handle birds to ensure the safety of the birds and themselves.

A variety of live-traps has been developed and effectively used to capture hawks and owls. Three of the most commonly used traps are discussed here, but more information is available in the listed references.

\section{Swedish Goshawk Trap}

The Swedish goshawk trap is a relatively large, semipermanent trap (Figure 4) that consists of two parts: a bait cage [such as a 3 × 3 × 1-foot cage made from 1-inch mesh welded wire] and a trap mechanism [consisting of a wooden or metal "A" frame, heavy springs to pull the doors closed nylon netting or chicken wire, and a trigger mechanism (often a hinged stick)] mounted on top of the 
bait cage. A hawk or owl dropping into the trap will trip the trigger mechanism and safely be trapped inside. Rock pigeons (Columba livia) are good lures because of their size, activity (movement is important for attracting hawks and owls), pest species status, and ease of care.

\section{$\underline{\text { Pole Trap }}$}

Pole traps are effective, especially where perching sites are limited. Pole traps consist of a specially modified foothold trap secured onto the top of a post or pole (using a wooden post, a metal pole, or PVC pile) to attract hawks and owls that use it for a hunting perch (Figure 5). When landing on the pole, the bird depresses the trap pan and the padded trap jaws will firmly but safely capture it. The trap is secured to a wire 'slide' that allows the trap and captured bird to slip to the ground.

Foothold traps (a 11/2 double-coil spring is a useful size) must be modified (weakened by removing one spring or by heat-treating before they are used for capturing hawks and owls). The jaws must be well padded with surgical tubing and wrapped with electrician's tape or foam rubber to protect the bird's leg (Figure 6).

The use of pole traps is prohibited in some states, and the USFWS has issued guidelines on their use for capturing problem hawks and owls. Contact your local WS office, state wildlife agency, and the regional USFWS permits office for authorization to use this capture method.

\section{Bal-chatri Trap}

The bal-chatri is a relatively small, versatile, and effective trap that can be modified to capture individual species of hawks and owls (Figure 7). Live small mammals or birds are used to lure raptors into landing on the trap, where nylon nooses entangle its feet and hold the bird until it is released.

Bal-chatri traps are commercially available, but are fairly easy to construct. There are several different sizes and shapes of bal-chatri traps, including the square-shaped, cone-shaped, and quonset hut type bal-chatris.

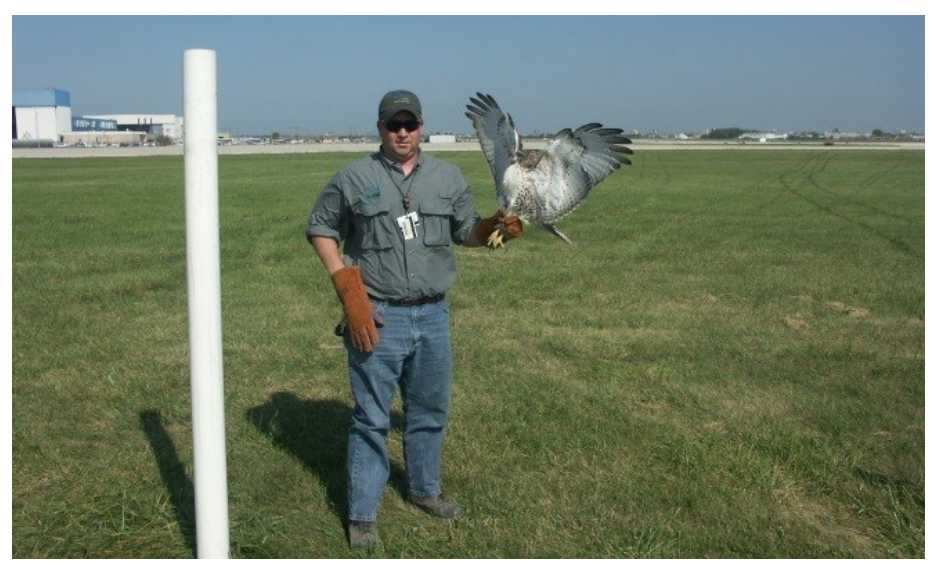

Figure 5. A biologist holds a young red-tailed hawk caught in a pole trap.

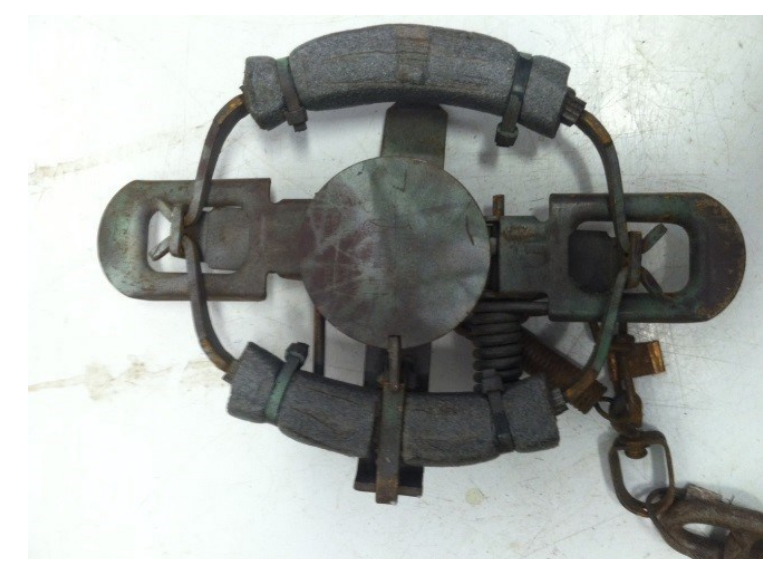

Figure 6. A modified foot-hold trap to live-capture raptors. The trap is weakened (a spring is removed) and the jaws are padded to protect the bird's leg.

Camouflaging traps is important; spray paint them before nooses are attached.

Bal-chatri traps should be secured with a 5- to 10-lb weight (exercise and barbell weights work well) or tied to a flexible branch to keep a trapped bird from dragging the trap and breaking the nylon nooses.

The quonset hut type bal-chatri was designed for trapping large hawks and owls. The trap is often made from 1-inch chicken wire, formed into a cage that is 18 inches long, 10 inches wide, and 7 inches high at the middle. The floor consists of 1-inch mesh welded wire with a lure entrance 
door and steel rod edging for ballast. The top is covered with about 80 nooses of 40 -pound test monofilament fishing line.

Selection of lures (bait animals) used in bal-chatri traps depends on the size and shape of the bal-chatri, as well as the species of hawk or owl being targeted. Rock pigeons, European starlings (Sturnus vulgaris), house mice (Mus musculus), and other small rodents can be used as lures.

Bal-chatri traps are effective only when placed where a perched or hunting raptor can see them. When placing traps, consider issues such as vehicles, large animals, and people who might crush, damage, or move the trap. These traps must be monitored continuously and caught birds removed as soon as possible, as the nooses will eventually break and release the bird.

\section{Other Traps}

In addition to the three traps mentioned above, many other traps have been used successfully to capture hawks and owls, including bow-nets, verbail traps, phai traps, dhogaza traps, mist nets, spring-net traps, whoosh nets, and the German "butterfly trap."

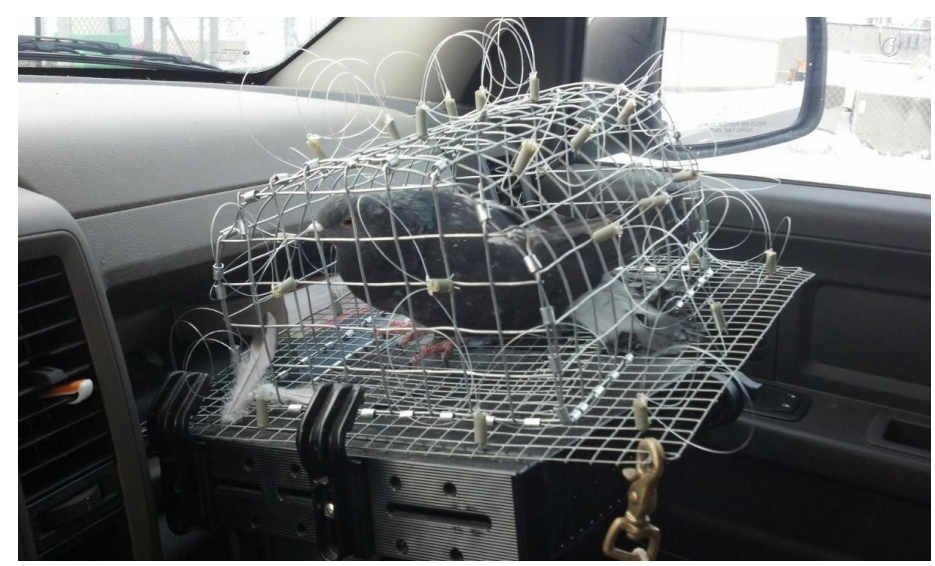

Figure 7. A bal-chatri trap. When a raptor attempts to capture the bait (a small rodent or bird), its talons are entangled in the nooses.

\section{Other Control Methods}

Keep yourself, children, and pets away from raptor nests when possible, to reduce the chance of aggressive nest defense behaviors. The presence of humans can be a deterrent to hawks and owls as they have a natural fear of people. Supervise small pets and livestock when they are outdoors to help decrease the potential of negative interactions with hawks and owls.

As with any human-wildlife conflict situation, public information and education regarding wildlife damage management, the ecology of wildlife species, and human perceptions and social values are essential components of an integrated wildlife damage management program.

\section{Handling}

If necessary and with some instruction, private citizens and landowners can safely handle and transport hawks and owls. The most important thing is to control the bird's feet. Talons can grasp a careless hand easily and inflict a painful injury. Risk of injury by the bird's wings and beak is significantly less. The safest approach, regardless of the type of trap, is to toss an old blanket or coat over both the bird and trap. Darkness calms most birds and makes them less able to defend themselves. Always wear heavy gloves (e.g., welding gloves) when handling raptors. Carefully reach under the blanket or coat with your hands and grasp the bird's lower legs. The feet must be gently but firmly controlled to avoid getting injured by the raptor's talons. Slowly pull the bird out of the trap so that it is clear of any object on which it could injure itself. Fold the wings down against the body and hold them securely.

Once the bird is safely secured, check it for any signs of external injury, such as cut feet or legs, excessively battered feathers, or scalping (the splitting of the skin over the forehead). If the bird is injured, have a local veterinarian examine it or transport it to the nearest federally licensed raptor rehabilitation center.

Restraining a raptor before transport reduces the chances of injury to both the bird and the handler. A commercial pet carrier or a stout, covered cardboard box makes a good 
raptor transportation cage. Select a carrier or box that is large enough for the bird to stand in upright. If using a pet carrier, place cardboard over the wire-mesh door to keep it dark inside. If using a cardboard box, punch holes near the bottom of the box to supply fresh air and keep the raptor from struggling toward any cracks of light coming from the top of a cardboard box.

Carry only one bird per box. Tape an old clean rag, towel, or piece of carpet to the floor of the carrier or box to provide a good gripping surface for the bird.

If possible, ask a local bird bander to attach a leg band prior to releasing the bird. Banding information can be useful to the research and management of raptors.

Transport the bird as quickly and comfortably as possible. Minimize excess handling and above all, keep the bird calm and cool (i.e., room temperature). More birds die from overheating during transport than from any other cause.

\section{Translocation}

Transport the bird as far away from the trapping site as reasonably possible. Red-tailed hawks and other raptors should be transported at least 75 to 100 miles from the capture site to minimize the probability of the bird returning. Choose a release site that appears to provide appropriate habitat and is not near an airport, poultry production facility, or major highway where future problems might ensue.

Birds trapped in the fall should be transported southward and birds trapped in the spring should be moved northward to help them along their migration path.

Obtain permission from the landowner to release birds onto private land and always carry a copy of your permits. Do not transport birds across a state line, as this is a violation of federal wildlife laws.

\section{Relocation}

Relocation of a bird (defined as moving an animal from one spot to another within its home range) is not a viable management option because the birds are not removed from the area where they are causing problems or inflicting damage. One exception is moving a bird out of a building or structure when it appears it cannot do so on its own. Rescue of a raptor trapped in a building does not require a federal permit provided the bird is not injured and is released immediately outside.

\section{Euthanasia}

Hawks and owls should not be euthanized. Sick or injured birds should be taken to a veterinarian or the nearest wildlife/raptor rehabilitation center. Hawks or owls injured or killed during efforts to capture them should be reported within 72 hours to the office that issued the permit.

\section{Disposal}

Possession of hawks and owls, their feathers, eggs, or body parts without a federal permit is a violation of federal law. If a hawk or owl needs to be disposed of, contact the USFWS or local state wildlife agency for assistance on proper procedures.

\section{Economics}

When considering which methods to use, consider the timing of such events, how cost-effective potential actions might be, whether the issue can be tolerated, and how the success of actions taken will be evaluated. Some methods will be too costly or impractical to implement, whereas other techniques can be quite easy to use and achieve the desired outcome. 


\section{Species Overview}

\section{Identification}

Hawks and owls are classified into four main groups, namely accipiters, buteos, falcons, and owls.

Accipiters typically are forest-dwelling hawks and include the northern goshawk (Accipiter gentilis), Cooper's hawk (A. cooperii), and sharp-shinned hawk (A. striatus). Accipters are recognized by their long-tailed, short-winged flight silhouette. Their flight pattern consists of several rapid wing beats, then a short period of gliding flight, followed by more rapid wing beats. Accipiters are seen most often during migration because they inhabit forested areas and are more secretive than many other hawks.

The buteos are broad-winged or soaring hawks. Of the 14 species of buteos in North America, the most common are the red-tailed hawk, red-shouldered hawk (Buteo lineatus), broad-winged hawk (B. platypterus), Swainson's hawk (B. swainsoni), rough-legged hawk (B. lagopus), and ferruginous hawk (B. regalis). Several North American buteos [e.g., the zone-tailed hawk (B. albonotatus)] are relatively rare and have very limited distributions in the United States. All buteos have long, broad wings and relatively short, fan-like tails. Buteos appear steady in flight and have powerful wing beats. They flap their wings for only short periods and rely on air thermals and updrafts to keep them in the air. Buteos generally soar over open country during their daily travels and seasonal migrations.

There are six species of falcons in North America: the American kestrel (Falco sparverius), merlin (F. columbari$u s)$, peregrine falcon ( $F$. peregrinus), prairie falcon ( $F$. mexicanus), gyrfalcon (F. rusticolus), and northern aplomado falcon ( $F$. femoralis septentrionalis). Falcons have long, narrow, pointed wings and are built for speed. These birds are adept at chasing down their prey, which often includes other birds in flight.

Owls are almost entirely nocturnal and thus are more difficult to observe. Exceptions include the snowy owl (Bubo scandiacus), short-eared owl (Asio flammeus), burrowing owl (Athene cunicularia), and northern hawk-owl (Surnia ulula). Owls have large heads and large, forward-facing eyes. They can approach prey with great stealth, due to the unique serrated edge of their feathers that dampens the sound of flight. This adaptation also slows their flight speed, but since most travel at night, slower flight reduces the risk of collisions and injury. Nineteen species of owls exist in the continental United States. They range in size from the tiny, 5- to 6-inch elf owl (Micrathene whitneyi) that resides in the arid Southwest, to the large, 24- to 33-inch great gray owl (Strix nebulosa) that inhabits the dense boreal forests of Alaska, Canada, and the northern continental United States. The most common and widespread is the great horned owl.

Although the sex of some hawks and owls can be determined from color patterns that are obviously different between males and females, males and females of most hawks and owls look very similar (in scientific terms, they are not sexually dimporhic in regard to plumage). Female hawks typically are larger than males. Often young birds are easily distinguished from older (breeding age) ones due to clear differences in coloration and feathers. Most notably, juvenile red-tailed hawks do not have the distinctive "red tail feathers" like breeding adults. There are many bird field guides available, several specific to hawks and owls, that can be helpful for determining the species, sex, and age of birds.

Given the number of different hawks and owls in North America, the potential for human-raptor conflict is significant. The northern goshawk, red-tailed hawk, and great horned owl account for the majority of conflicts between humans and hawks and owls. This publication focuses on these three species, but most of the general biology, nature of conflicts, and damage management methods will apply to other hawks and owls.

\section{Physical Description}

\section{Northern Goshawk}

The northern goshawk (Figure 8) is the largest but least common of the three North American accipiters. Goshawks are 20 to 26 inches tall and weigh from 1 pound 7 ounces 


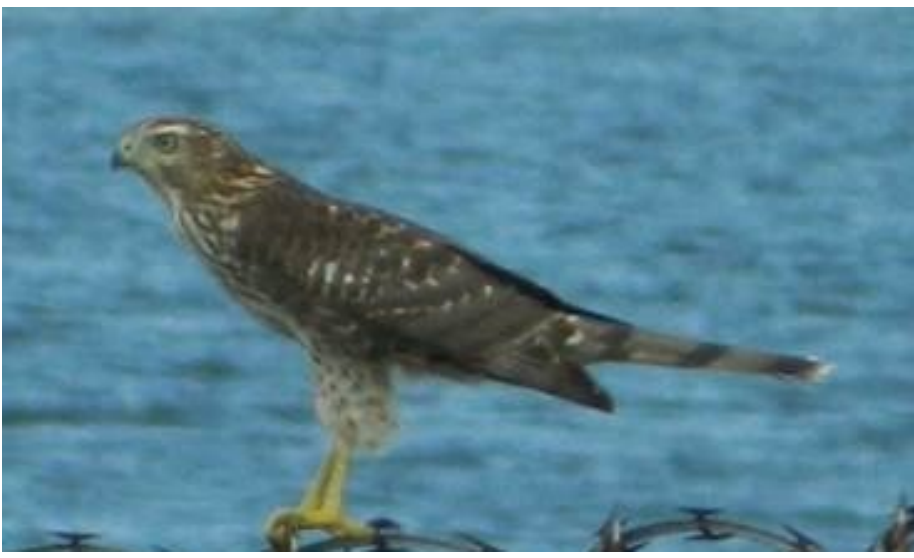

Figure 8. A sub-adult northern goshawk (Accipitergentilis), an accipiter.

to 2 pounds 10 ounces. Goshawks have broad wings that taper toward the tips, and a long, broad tail. Juvenile goshawks have a broad, pale superciliary line (line of feathers above the bird's eye) and grey cheeks, whereas adults have blackish heads and a bright white superciliary line.

\section{Red-tailed Hawk}

Red-tailed hawks (Figure 9) are large, stout, and powerful birds-the quintessential buteo. Red-tails are 19 to 25 inches tall and weigh from 1 pound 9 ounces to 3 pounds 8 ounces. They have long and broad wings and wide tails. Red-tailed hawks exhibit an extreme amount of color variation throughout North America, from very light colored or pale and to very dark. Juvenile red-tailed hawks lack the distinct red tail feathers, the namesake of this species. Red-tailed hawks often are seen in open areas soaring high above the ground.

\section{Great Horned Owl}

Great horned owls (Figure 10) are large, powerful owls with iconic ear tufts or "horns" and a very characteristic white throat "bib." They are colorful birds with dark bars on their breast feathers. Great horned owls are 18 to 25 inches tall and weigh from 1 pound 7 ounces to 3 pounds 15 ounces. Great horned owls are secretive and not often seen, spending much of their time perched in wooded areas.

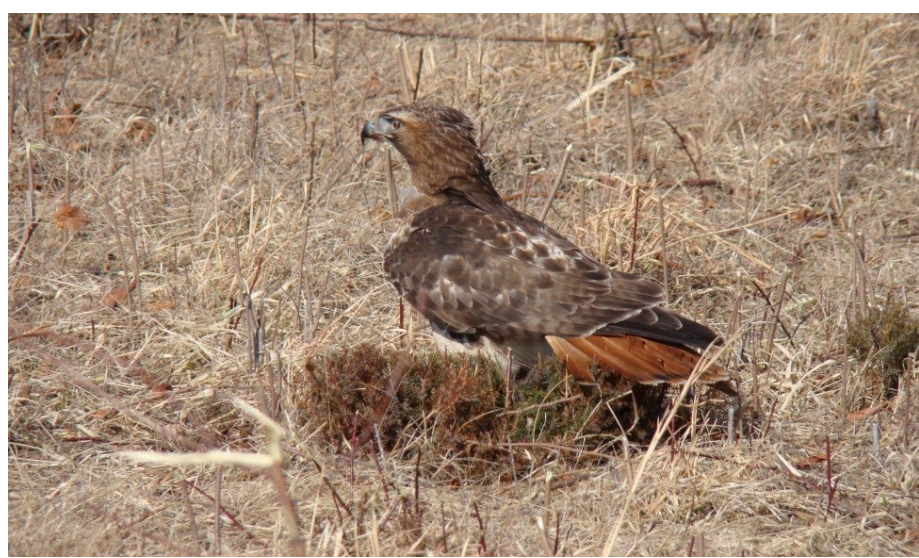

Figure 9. An adult red-tailed hawk (Buteo jamaicensis), a typical buteo).

\section{Range}

Some hawks and owls are widely distributed across North America, while others have very limited distributions and occur in very small areas or in just one state. Information about other hawks and owls, including their ranges and other aspects of their biology, can be found in bird field guides, in several books about raptors, and within on-line resources, such as The Birds of North America series (See Appendix 2 for northern goshawk, red-tailed hawk and great horned owl range maps).

The northern goshawk occurs primarily in northern and western North America. Many goshawks exhibit migratory behaviors and, during certain years, large numbers of these birds move south and winter in the northeastern and north-central United States.

The red-tailed hawk is one of our most common and widely distributed raptors with 16 recognized subspecies. They can be found throughout the entire North American continent south of the treeless tundra and in much of Central America. They demonstrate a remarkably wide ecological tolerance for nesting and hunting sites throughout their extensive range.

The great horned owl is the most widely distributed raptor in North America. Its range extends over almost all of North America except for the extreme northern regions of the Arctic. 


\section{Voices and Sounds}

Hawks and owls typically have calls that are specific to their own species. The iconic "kee-eeee-arrr" of the redtailed hawk and the "who-ho-o-o, whoo-hoo-o-o, whoo" of a great horned owl are notable examples. Although hawks and owls tend to be relatively quiet, which aids in hunting, they can be quite vocal during the breeding and nesting seasons.

\section{Tracks and Signs}

Hawks and owls typically do not leave tracks unless there is fresh snow cover. One key sign that indicates the presence of hawks and owls is pellets or castings, which are regurgitated masses of undigested food items. Fresh pellets, especially of owls, are covered with a moist iridescent sheen. They can be very helpful in identifying what species of bird might be involved in a predation situation and provide valuable information about the feeding habits of raptors.

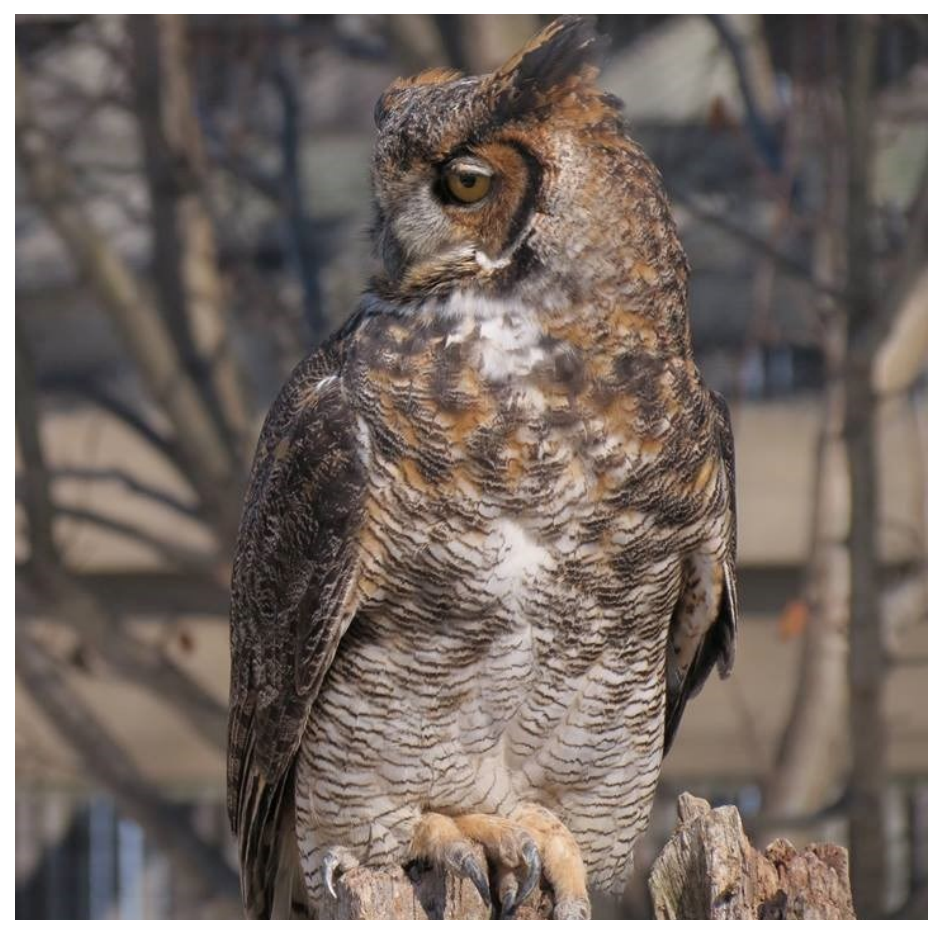

Figure 10. An adult great horned owl (Bubo virginianus).

\section{Reproduction}

Northern goshawks typically begin breeding at 2 to 3 years of age. Both sexes show some fidelity to their nesting territories, meaning the same male and female typically return to the same nest location year after year. In North America, the breeding season generally is from April to July. Mature goshawks attempt to nest only once per year and the average clutch size is 2 to 4 . Similar to most hawks and owls, the abundance and availability of prey strongly influences reproductive output of this species. On average, each nesting pair of goshawks produces 2.0 to 2.8 young per year.

Red-tailed hawks typically begin breeding at 3 years of age. They exhibit a high degree of fidelity to their nesting territories. In North America, the breeding season generally is from March to July. Mature red-tailed hawks attempt to nest only once per year, and the average clutch size is 2 to 3. Reproductive output in this species varies by the abundance of available prey, density of hunting perches, and the proximity of their nests to those of other red-tailed hawks. On average, each nesting pair successfully fledges 0.9 to 1.4 young per year.

Great horned owls typically begin breeding at 2 years of age. In a given year, many adults fail to establish territories and breed; these birds are referred to as floaters. In North America, the breeding season generally is from February to April. Mature great horned owls typically attempt to nest once per year and have an average clutch size of 2 to 3 . Although the reproductive output of this species varies by the abundance of available prey, each nesting pair successfully produces an average of 0.5 to 2.6 young per year.

\section{Nesting}

Northern goshawks nest in a variety of forested habitats, but show a strong preference for large tracts of forest with mature trees, closed canopies, open understories, and sparse ground cover. Human disturbances, such as timber harvesting, during the breeding season can cause nest abandonment and failures. 
Red-tailed hawks demonstrate a remarkably wide ecological tolerance for nesting sites throughout their extensive range. In eastern North America, they typically nest in mature forests and woodlots, while they often nest on cliffs, trees, and cacti in the Southwest. These hawks often are tolerant of people and nest in urbanized areas. One of the most famous is "Pale Male," which received much media attention when it nested on a building in Manhattan (New York City).

Great horned owls use a wider range of nest sites and nesting habitats than any other raptor in North America. Great horned owls usurp tree nests built by other birds, most commonly red-tailed hawks or squirrels. They also use cavities in trees, cliffs, deserted buildings, and a variety of other nesting locations.

\section{Mortality}

In North America, shooting and trapping are not considered to be important mortality factors for northern goshawks. Goshawks are more actively persecuted in Europe in relation to private game bird farms. Habitat loss and degradation is the primary threat to nesting populations of northern goshawks.

Historically, the greatest source of mortality in red-tailed hawks has been intentional shooting by humans. Red-tail hawks face a variety of other human-related mortality issues that may be locally or regionally important, including collisions with vehicles (cars, trains, aircraft) and structures (towers, fences, wind turbines), electrocutions, and secondary poisoning from pesticides and lead ingestion.

Annual survival rates for great horned owls generally are unknown, but likely show patterns similar to those of hawks and other owls. Human-caused mortality, both direct and indirect, accounts for most of the deaths in great horned owls. Illegal shooting, non-intended secondary poisoning from pesticides, and collisions with vehicles, are common causes of mortality.

\section{Population Status}

Northern goshawks are the least common of the three North America accipiters covered here, but overall they are fairly abundant regionally. With the exception of the Queen Charlotte Goshawk subspecies, the northern goshawk is not listed as federally threatened or endangered in North America. Goshawks are considered to be a management indicator species by the U.S. Forest Service because they are sensitive to habitat change.

Populations of red-tailed hawks in North America are stable or increasing. Red-tailed hawks are considered the most abundant hawk in North America, a trend that will likely continue due to this species' adaptability and success in landscapes created by urban and exurban sprawl.

The great horned owl likely is stable or increasing across North America. They are very common, and local population densities are linked to the availability of prey.

\section{Habitat}

Northern goshawks inhabit large forested areas during the breeding season and forage along grassland-forest edges, within forest openings, and within riparian areas. Nesting territories are 2.2 to 13.5 square miles. Goshawks typically have 1 or 2 core areas where much of their hunting and activities occur. Not much is known about wintering home ranges of northern goshawks.

Throughout its extensive range, the red-tailed hawk typical inhabits open areas interspersed with patches of trees or similar structures. Although it varies due to several factors, most notably food availability, territories of red-tailed hawks range from 0.5 to 1.0 square miles.

Great horned owls use a wide variety of habitats, including deciduous and coniferous forests, open and second-growth woodlands, swamps, orchards, and agricultural areas. They commonly occupy wooded residential parks and urban and exurban areas. Territories of great horned owls range from 0.3 to 1.0 square miles, although floater owls that do not establish territories use areas approximately 5 times larger. 


\section{Behavior}

Northern goshawks typically are diurnal (or active during the day), and begin to hunt at first light. Goshawks are adapted to hunt on the wing, and can effectively chase down prey in brushy or wooded areas. They have been known to chase poultry into buildings. Goshawks roost alone, high in the tree canopy.

Red-tailed hawks are diurnal and feed during daylight hours. They hunt from perches or soar over areas and search for prey, diving down to take birds and mammals. They roost in trees with dense foliage, typically alone or with only 1 or 2 other hawks.

Great horned owls are nocturnal and typically hunt at night or early morning hours. They hunt from perches, listening and watching for the movements of prey. They roost in trees, snags, thick brush, buildings, and cavities.

\section{Food Habits}

The northern goshawk is a bold, opportunistic predator that feeds on a variety of birds and mammals, but mainly on ground squirrels, tree squirrels, rabbits, hares, large passerine birds, woodpeckers, grouse, pheasants, other game birds, and crows.

The diet of red-tailed hawks can be extremely diverse, but usually contains small to medium-sized mammals such as mice and voles, tree and ground squirrels, rabbits and hares; game birds such as pheasants and quail; small birds such as starlings and blackbirds; and reptiles such as snakes and lizards. Red-tailed hawks also scavenge on fresh carrion, including road-killed animals.

Great horned owls have the most diverse prey profile of all North American raptors. They opportunistically feed on a wide variety of mammals, birds, reptiles, amphibians, fish, and invertebrates. Their diet typically consists of mammals such as ground squirrels, rats and mice, muskrats, woodchucks and skunks; but shorebirds, ducks, pigeons, doves, and other owls can be important. Nestlings and fledglings of many bird species, including raptors, also can be an important seasonal food for great horned owls.

\section{Legal Status}

All hawks and owls in the United States are federally protected under the Migratory Bird Treaty Act (16 USC, 703-711). Hawks and owls typically are protected under state wildlife laws or local ordinances, as well. These laws strictly prohibit the capture, killing, or possession of hawks or owls (or their parts) without a special permit (e.g., Federal Depredation Permit), issued by the USFWS. State-issued wildlife damage or depredation permits also may be required. Permits are not required to frighten or harass depredating migratory birds unless the birds are endangered or threatened (see Table below).

Some hawks and owls may be common in one state but categorized as being threatened or endangered in another state. Consult with your local Wildlife Services, USFWS, and state wildlife agency personnel for permit requirements and information.

\begin{tabular}{|c|c|c|}
\hline Common Name & Scientific Name & Historic Range \\
\hline \multicolumn{3}{|c|}{ Endangered Status } \\
\hline California Condor & $\begin{array}{l}\text { Gymnopyps } \\
\text { californianus }\end{array}$ & $\begin{array}{l}\text { U.S. (AZ, CA, OR) } \\
\text { and Mexico }\end{array}$ \\
\hline $\begin{array}{l}\text { Northern } \\
\text { Aplomado Falcon }\end{array}$ & $\begin{array}{l}\text { Falco feromalis } \\
\text { septentrionalis }\end{array}$ & U.S. (AZ, NM) \\
\hline $\begin{array}{l}\text { Hawaiian } \\
\text { Hawk }\end{array}$ & $\begin{array}{l}\text { Buteo } \\
\text { solitarius }\end{array}$ & U.S. (HI) \\
\hline $\begin{array}{l}\text { Puerto Rican } \\
\text { Broad-winged } \\
\text { Hawk }\end{array}$ & $\begin{array}{l}\text { Buteo platypterus } \\
\text { brunnescens }\end{array}$ & $\begin{array}{l}\text { U.S. } \\
\text { (Puerto Rico) }\end{array}$ \\
\hline $\begin{array}{l}\text { Puerto Rican } \\
\text { Sharp-shinned } \\
\text { Hawk }\end{array}$ & $\begin{array}{l}\text { Accipiter striatus } \\
\text { venator }\end{array}$ & $\begin{array}{l}\text { U.S. } \\
\text { (Puerto Rico) }\end{array}$ \\
\hline $\begin{array}{l}\text { Everglade Snail } \\
\text { Kite }\end{array}$ & $\begin{array}{l}\text { Rostrhamus socia- } \\
\text { blis plumbeus }\end{array}$ & U.S. (FL) and Cuba \\
\hline \multicolumn{3}{|c|}{ Threatened Status } \\
\hline $\begin{array}{l}\text { Mexican } \\
\text { Spotted Owl }\end{array}$ & $\begin{array}{l}\text { Stix occidentalis } \\
\text { Iucida }\end{array}$ & $\begin{array}{l}\text { U.S. (AZ, CO, NM, } \\
\text { TX, UT) and Mexico }\end{array}$ \\
\hline $\begin{array}{l}\text { Northern } \\
\text { Spotted Owl }\end{array}$ & $\begin{array}{l}\text { Strix occidentalis } \\
\text { caurina }\end{array}$ & $\begin{array}{l}\text { U.S. (CA, OR, WA) } \\
\text { and Canada }\end{array}$ \\
\hline $\begin{array}{l}\text { Queen Charlotte } \\
\text { Goshawk }\end{array}$ & $\begin{array}{l}\text { Accipter gentilis } \\
\text { laingi }\end{array}$ & $\begin{array}{l}\text { Canada (British } \\
\text { Columbia) }\end{array}$ \\
\hline
\end{tabular}




\section{Acknowledgements}

Figure 1. Photo by Brian E. Washburn, USDA-APHIS-WS, NWRC Figure 2. Photo by Anson Eaglin, USDA-APHIS

Figure 3. Photo by Christopher Loftis, USDA-APHIS-WS

Figure 4. Photo by Todd Pitlik, USDA-APHIS-WS

Figure 5. Photo by Brian E. Washburn, USDA-APHIS-WS, NWRC

Figure 6. Photo by Brian E. Washburn, USDA-APHIS-WS, NWRC

Figure 7. Photo by Brian E. Washburn, USDA-APHIS-WS, NWRC

Figure 8. Photo by Jenny Washburn, USDA-APHIS-WS

Figure 9. Photo by Jenny Washburn, USDA-APHIS-WS

Figure 10. Photo by Jenny Washburn, USDA-APHIS-WS

\section{Glossary}

Acclimate: A degredation in response to repeated stimulation such that the animal no longer reacts to the use of a scare tactic or device.

Clutch size: The number of eggs laid in a nest by a breeding bird.

Floater: Adult raptor that fails to establish a territory and breed.

Pellet: The regurgitated mass of undigested parts of a bird's food, consisting of undigested bones, feathers, fur and hair from prey items.

Plumage: The layer of feathers that cover a bird and the pattern, color, and arrangement of those feathers.

Pyrotechnics: Flares or cartridges fired from a gun or launcher that produce a loud blast or scream accompanied by smoke and a flash of light.

Raptor: Also known as a bird of prey, a bird that hunts and eats other animals.

Relocation: The act of moving an animal from one spot to another. For example, moving a bat from your attic to the backyard.

Sexually dimorphic: A physical or observable difference between males and females of the same species.

Superciliary line: A line of feathers above a bird's eye.

Translocation: The act of moving an animal outside of its original home range, usually a considerable distance away.

\section{Key Words}

Exclusion, Game birds, Hawks, Livestock, Owls, Poultry, Raptors, Trapping, Translocation

\section{Disclaimer}

Wildlife can threaten the health and safety of you and others in the area. Use of damage prevention and control methods also may pose risks to humans, pets, livestock, other non-target animals, and the environment. Be aware of the risks and take steps to reduce or eliminate those risks.

Some methods mentioned in this document may not be legal, permitted, or appropriate in your area. Read and follow all pesticide label recommendations and local requirements. Check with personnel from your state wildlife agency and local officials to determine if methods are acceptable and allowed.

Mention of any products, trademarks, or brand names does not constitute endorsement, nor does omission constitute criticism.

\section{Citation}

Washburn, B.E. 2016. Hawks and Owls. Wildlife Damage Management Technical Series. USDA, APHIS, WS National Wildlife Research Center. Ft. Collins, Colorado. 17p. 


\section{Resources}

Artuso, Christian, C. Stuart Houston, Dwight G. Smith and Christoph Rohner. 2014. Great Horned Owl (Bubo virginianus), The Birds of North America Online (A. Poole, Ed.). Ithaca: Cornell Lab of Ornithology; The Birds of North America Online: http://bna.birds.cornell.edu/bna/species/372

Berger, D. D., and F. Hamerstrom. 1962. Protecting a trapping station from raptor predation. Journal of Wildlife Management 26:203-206.

Bird, D. M., and K. L. Bildstein (Editors). 2007. Raptor research and management techniques. Hancock House Publishing, Blaine, Washington, USA. 463 pp.

Bub, H. 1991. Bird trapping and bird banding. (English translation edition). Cornell University Press, Cornell, New York, USA. $330 \mathrm{pp}$.

Dunn, J. L., and J. Alderfer. 2011. National Geographic Field Guide to the Birds of North America. 6th Edition. National Geographic Society, Des Moines, lowa, USA. 576 pp.

Elbroch, M., and E. Marks. 2001. Bird tracks and sign: a guide to North American species. Stackpole Books, Mechanicsburg, Pennsylvania, USA. 456 pp.

Liguori, J. 2011. Hawks at a distance. Princeton University Press, Princeton, New Jersey, USA. 193 pp.

Meng, H. 1971. The Swedish goshawk trap. Journal of Wildlife Management 35:832-835.

Newton, I. 1979. Population ecology of raptors. Buteo Books, Vermillion, South Dakota. 399 pp.

Preston, C. R. and R. D. Beane. 2009. Red-tailed Hawk (Buteo jamaicensis), The Birds of North America Online (A. Poole, Ed.). Ithaca: Cornell Lab of Ornithology; The Birds of North America Online: http://bna.birds.cornell.edu/bna/ species/052

Squires, John R. and Richard T. Reynolds. 1997. Northern Goshawk (Accipiter gentilis), The Birds of North America Online (A. Poole, Ed.). Ithaca: Cornell Lab of Ornithology; The Birds of North America Online: http://bna.birds.cornell.edu/ bna/species $/ 298$

US Department of the Interior, US Fish and Wildlife Service. 2005. Use of pole traps for capturing depredating raptors. Migratory Bird Permit Memorandum MBPM-4. Washington, DC. 5 pp.

US Department of the Interior, US Fish and Wildlife Service Federally Listed Threatened and Endangered Species www.fws.gov/endangered/

US Department of the Interior, US Fish and Wildlife Service, Permits www.fws.gov/migratorybirds/mbpermits.html 


\section{Appendix 1}

\section{Damage Management Methods for Hawks and Owls}

\begin{tabular}{|c|c|}
\hline Type of Control & Available Management Options \\
\hline Exclusion & $\begin{array}{l}\text { - When practical and economical, confinement is the most effective method for } \\
\text { - } \quad \text { Confine free-ranging fowl in enclosures covered with netting or woven wire } \\
\text { - } \quad \text { House fowl at night to protect from owls } \\
\text { - } \quad \text { Use anti-perching devices (sheet metal cones, Nixalite } \AA \text {, Cat Claws }{ }^{\circledR} \text {, or inverted } \\
\text { spikes) on structures and poles }\end{array}$ \\
\hline Frightening Devices & Air horns, scarecrows, and pyrotechnics as allowed by local laws and ordinances \\
\hline Habitat Modification & Eliminate nearby perch sites (cut down large, isolated trees and snags) \\
\hline Repellents & None available \\
\hline Toxicants & None available \\
\hline Trapping & $\begin{array}{ll}\text { - } & \text { State and federal permits are required } \\
\text { - } & \text { Variety of live-traps (e.g., pole traps, Swedish goshawk traps, bal-chatri traps) } \\
\text { - } & \text { Raptors must be translocated far from the problem site where captured }\end{array}$ \\
\hline Shooting & $\begin{array}{l}\text { - } \quad \text { Can be authorized under certain conditions } \\
\text { - Federal depredation permits are used only when public health and safety is an issue } \\
\text { and non-lethal methods are ineffective }\end{array}$ \\
\hline Other Methods & $\begin{array}{l}\text { - Keep yourself, children, and small pets a safe distance (e.g., } 500 \text { feet) from active } \\
\text { raptor nests } \\
\text { - } \quad \text { Do not leave small pets (e.g., cats, small dogs) unattended outdoors } \\
\text { - } \quad \text { Provide safe enclosures or bring small pets inside at night }\end{array}$ \\
\hline
\end{tabular}




\section{Appendix 2}

Range Maps for Northern Goshawk, Red-tailed Hawk, and Great Horned Owl.

Maps by The Birds of North America Online, Cornell Lab of Ornithology.

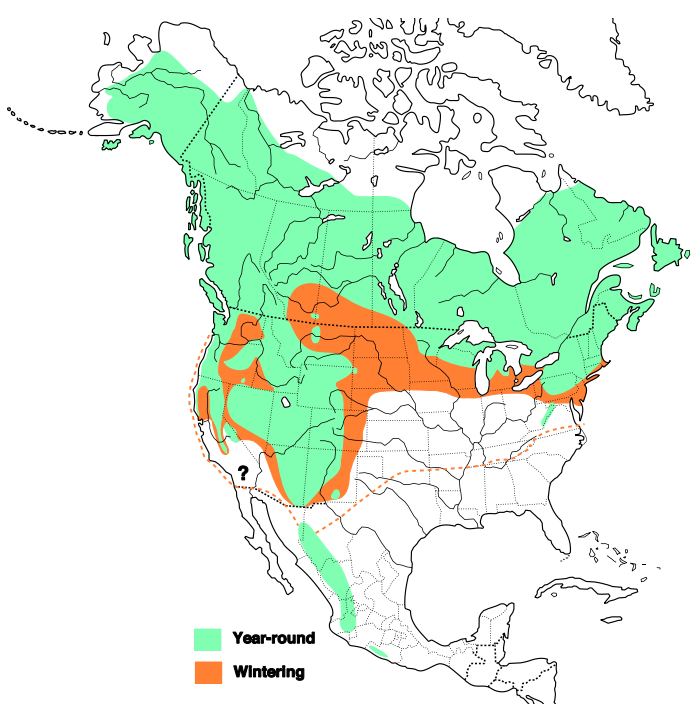

Range of the northern goshawk in North America.

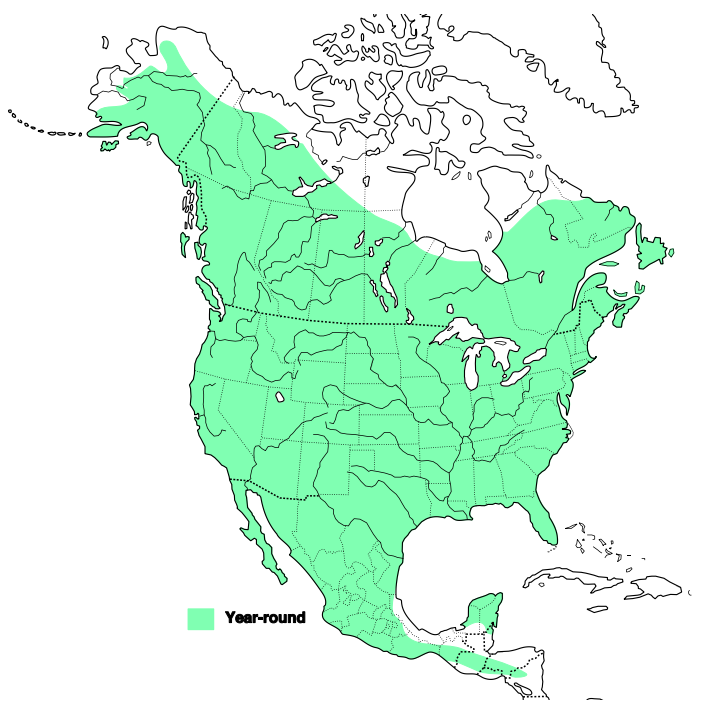

Range of the great horned owl in North America.

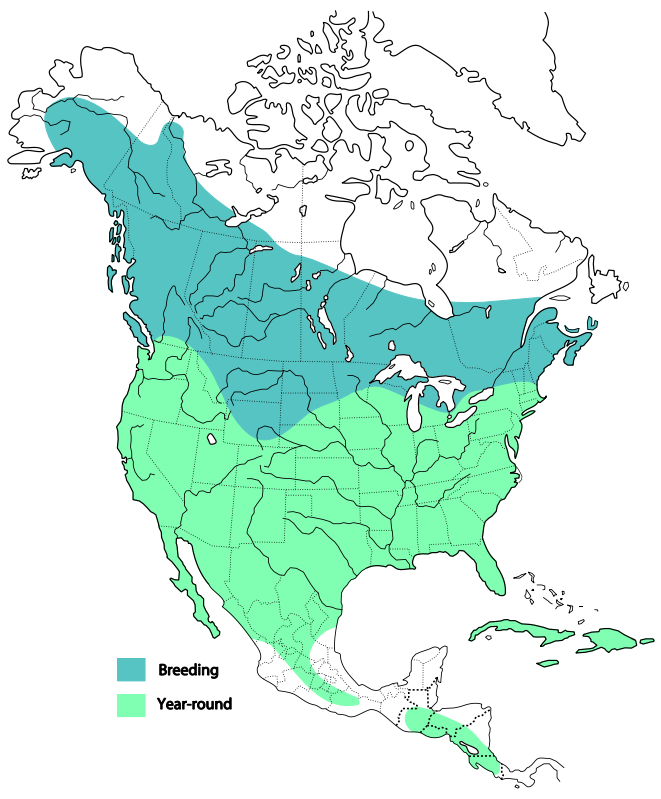

Range of the red-tailed hawk in North America. Birds in the breeding area (blue) are migratory. 